\title{
Family Law: High Economic and Bachelor's Moeslem Couples Divorce Suit in Bandar Lampung City
}

\author{
Nunung Rodliyah ${ }^{1}$, Ade Oktariatas $\mathrm{K}^{2}$ \\ \{nunungradliyah@yahoo.com ${ }^{1}$, adeoktariatasky@outlook.com²
}

University of Lampung, Lampung, Indonesia ${ }^{1}$; University of Lampung, Lampung, Indonesia ${ }^{2}$

\begin{abstract}
The freedom of the population to obtain the highest education has not had a full impact on the level of marriage. Divorce in the Religious Courts itself does not only originate from the husband's divorce, but also from the wife's lawsuit which is currently rife with wives who feel that the relationship between husband and wife has problems that cannot be resolved with their partners. The legal issues discussed in the research are the causes of divorce suits that are more frequent and increasing every year and what are the factors behind the highly educated divorce population? The scope of the research carried out is in the Klas I Tanjung Karang Religious Court in Bandar Lampung City. The writing method uses a normative and empirical approach. The results of the study show that it provides a solution for the entire community and government agencies to work together to support the bride and groom to prepare physically and mentally for the commitment to build a family that is in accordance with the ideals of law and religion in realizing a happy family with one. one more for life and to minimize any prolonged conflict after marriage that could lead to divorce.
\end{abstract}

Key Words: Marriage, Moeslem Couples, Education, Divorce Suit, Gender

\section{Introduction}

The provisions of laws and regulations in Indonesia, the term marriage / marriage actually goes far beyond the term marriage formulated by scholars' in their various fiqh literatures. In law number 1 of 1974 it is explained that: "Marriage is a physical and mental bond between a man and a woman as husband and wife with the aim of forming a happy and eternal family (household) based on one one godhead".

Ibn Al-Haytham explained that the concept of happiness is the freedom of the soul from something that grips it, either in the form of pain (rabab min alam) or from something other than pain (rahah min ghayr alam). Happiness because, freeing the soul from sorrow, for Ibn Al-Haytham, is not true happiness. Happiness like this is sought not because of what is sought in itself, but because of something else. When something that is sought has been achieved, the soul tends not to want it anymore. Happiness like this is a type of happiness that is temporary and not essential, this happiness is exemplified as a human being in a hungry state who is in a state of suffering and experiencing physical pain.[1]

Muhammad Abu Zahrah said that marriage / marriage is "a contract which has legal consequences in the form of halting intercourse between a man and a woman, helping each other and creating rights and obligations between the two." M. Azhar Basyir defines "Marriage is doing a contract or agreement to bind oneself between a man and a woman to legalize sexual relations between the two parties on a voluntary basis and the pleasure of both parties to realize a happy family life filled with affection. and peace in ways that are pleasing to Allah. 
Husband and wife must be responsible for meeting each other's needs to build a harmonious and peaceful family. For the sake of success in realizing building a harmonious and peaceful family, it is necessary to have togetherness and an attitude of sharing responsibility between husband and wife. The Al-Qur'an recommends cooperation between them. In the al-Qur'an it is stated, that a husband and wife are to get along (in) good terms, in ma'ruf terms as emphasized by Allah SWT. in Q.S. An-Nisa '(4): 19. (Whereas what is said to interfere with a wife who is good is: (1) respect, respect, and good treatment, (2) increases the standard of life in the fields of religion, morals, and the necessary knowledge, (3) protects and maintaining the good name of the wife, (4) meeting the biological needs of the wife).

Carrying out the fundamental provisions of the Al-Qur'an as the main source of law of Islamic law, must be accompanied by the provisions of the Sunnah of the Prophet and Rasul. The discussion of Al-Sunnah within the scope of Islamic institutions refers to the meaning of the religious traditions pursued and carried out by the Prophet, on his missionary journey, including religious messages that were conveyed orally or acts of good behavior, and were recognized by his followers continuously from the early period, either in the form of teachings that come from Allah (the Qur'an) and from the Prophet himself.[2]

Every marriage is expected to last a lifetime. However, there are times when the journey across the household ark is not always smooth as expected, you must face obstacles that become problems in the household. If the problem is not resolved properly, it will cause a dispute and lead to divorce. But if the household can not be maintained, and if it is maintained it will cause prolonged strife and suffering. Islam is not absolutely binding on marriage, but it does not make divorce easier.

Divorce is part of a legal event that couples who are bound by the law of marriage are very much avoided, but it does not rule out as a last resort if the marital relationship is declared no longer in the harmonious category. The findings of the research that the author has conducted on the causes of divorce in the Muslim community in the Religious Courts (2006) and studies of several researchers have revealed that the divorce rate in urban areas is higher than in rural areas. This phenomenon is caused by several things, including people who have seen the stigma of divorce as a common thing in marriage and others.

In recent years, divorce has become a very popular term in the ears of the public, this is because the divorce rate continues to grow. There are always in the religious court every day several couples who have been married have changed their status to become widows / widowers. Interestingly, the large number of divorces is dominated by the number of divorcees (divorces submitted by the wife).

UU no. 14 of 1970, which has united the Religious Courts in an integral national justice system, needs to be reaffirmed in a special regulation, because later the Religious Courts could be merged with the General Courts, so it is necessary to establish a Law on Religious Courts. This effort then bore fruit in 1989 with the passing of Law no. 7 of 1989 concerning Religious Courts.[3]

Table.1 Divorce Case Decided at the Class IA Tanjung Karang Bandar Lampung Religious Court 2015-2019

\begin{tabular}{ccccc}
\hline No & Years & $\begin{array}{c}\text { Thalaq } \\
\text { Divorce }\end{array}$ & $\begin{array}{c}\text { Suit } \\
\text { Divorce }\end{array}$ & Total \\
\hline 1 & 2015 & 162 & 291 & 353
\end{tabular}




\begin{tabular}{lllll}
2 & 2016 & 169 & 294 & 363 \\
3 & 2017 & 186 & 236 & 422 \\
4 & 2018 & 223 & 298 & 521 \\
5 & 2019 & 230 & 410 & 640 \\
\hline
\end{tabular}

Based on the data above, it can be seen that every year the divorce rate tends to increase. In 2015, the number of divorce cases decided was 353, then increased to 363 in 2016, then increased to 422 in 2017, then increased to 521 in 2018, and increased in 2019 to 640 cases.

Of the divorce cases that have been decided, there are more litigated divorces compared to divorce divorces from 2015 to 2019. In fact, in 2015 the number of divorcees was almost twice as high as divorce thalaq.

This research discusses the scope of efforts to suppress the high divorce rate in society, in fact the Indonesian government has regulated the divorce issue to limit the divorce rate, such as divorce can only be done in front of a court (Article 39 of Law Number 1 of 1974; Article 115 Compilation of Islamic Law), and divorce can occur for certain reasons (Article 19 of Government Regulation Number 9 of 1975; Article 116 Compilation of Islamic Law).

Marriage should be interpreted as a contract that will give birth to complex implications in domestic life, so that every individual who is included is capable (istitha '), which means being able to face the complexities of his domestic life. From here the points of marriage that should be actualized in the present life, towards eternal home life.

Based on the background of the legal issues, the main problems in this research are, 1) Why is divorce more prevalent and increasing every year? and 2) What are the factors behind the divorce of the highly educated population? The scope of the issue is accommodated from one area, namely the area of the Class I Religious Court of Bandar Lampung City.

\section{Method}

The approach to the problem used in this study is a normative and empirical approach. The normative approach to the problem, namely the approach taken by studying, examining the provisions / inventory of the laws and regulations related to the Marriage Law in connection with the divorce case. The inventory results are then classified in order, supported by supporting legal materials in the form of scientific articles, case studies, and expert opinions. Then in enriching the discussion it is supported by an empirical problem approach, namely the problem approach that is carried out with the direct problem conditions that exist, in this case a contested divorce which is handled by the Class I Religious Court of Bandar Lampung City. This is done so that the systematization of the formulation of the problem raised produces concrete discussions and clearly explains the science of law that implements its enforcement in the community.

\section{Discussion}

\subsection{Increase in Divorce Claims Every Year}

Marriage should be interpreted as a contract that will give birth to complex implications in domestic life, so that every individual who is considered capable (istitha') means being able to face the complexities of his domestic life. From here the points of marriage that should be actualized in this life, to an eternal household life as aspired by the Al-Qur'an with the term 
mitsaqan ghalidzan (strong and strong ties). When there is a dispute between the two parties, Islam does not directly ask the husband and wife to end the marriage,[4] but a deliberation is carried out first.

Divorce is often an option / compulsion that cannot be avoided by married couples, especially if the household relationship can no longer be maintained. Therefore, both Islamic law and government law provide a way according to the background of the case. Divorce in Islamic law is better known as Thalaq, which is to untie the bonds (hall al-Qaid), to release the bonds by using predetermined words. In Islam, basically Thalaq is an act that is permissible (halal) even though it is also something that is hated (makruh).

The absence of household harmony is the main cause of divorce, followed by a moral crisis which occupies the second cause of divorce in the people of Bandar Lampung, which is 11 cases or $22 \%$, followed by absence of responsibility is the dominant factor affecting the divorce that occurs in the Muslim community of the city of Bandar Lampung. Respondents admitted that their husbands were often drunk, gamblers, and prostitutes so that the respondents were not happy with them. One example is he goes to work, it turns out that he comes home drunk and even comes home late at night, his body is unbalanced and he drinks too much.

By paying 'iwad' is the same as the right given to a husband to divorce his wife, then his wife can sue for divorce if the marriage was not her own will or was imposed by her parents. Divorce is often filed by wives if they feel physically or mentally tormented. Because from the beginning there was no sense of love in the marriage, so divorce was considered the best solution for the wife to be released from the marriage bond which actually made life tormented. KHI in Article 116 point (a) also justifies these reasons, namely: one of the parties commits adultery or becomes a drunkard, a prostitute, a gambler and others who are difficult to cure. Divorce is also a cause of the wife's right. The wife is given the right to commit a legal act which is the cause of the break-up of the marriage, the legal act is khul'un.[5] The wife asks her husband to break the marriage bond by means of the wife providing payment to redeem herself to the husband.

Many factors cause divorce, including economic factors, infidelity by one partner, disharmony in the family, incompatibility in the household, the presence of a third party, due to early marriage, and so on.

\subsection{High Economic and Bachelor's Moeslem Couples Divorce Factors}

Some indications of social changes that are quite influential in divorce:

1) Changes in the meaning contained in divorce, in the current sense that divorce is no longer considered a disgrace, in big cities the status of a widow or widower is a common thing because city people emphasize their role more than their individual status;

This stigma is increasingly prevalent in the community, considering that the existence of urban communities is not only seen from the level of marriage but also career achievements, especially those based on material values that are accommodated as living standards. The essence of marriage which must be in line with the careers carried out by husband and wife partners must synergize with each other, assist the authorities during pre-marriage, then the awareness of the partners to build good communication as long as they are married, and knowledge, scientific insight regarding the marriage that is Couples must have to overcome internal problems in the family must be strengthened, because the factor of higher education in this case is only as education that supports career orientation, often eroding the insight of 
maintaining the integrity of the marriage which basically goes hand in hand with careers when a partner is bound by a marriage event.

2) Changes in loosening supervision of relatives, friends, and neighborhoods on family integrity;

Along with the times and development, the city of Bandar Lampung, which was originally an entity based on rural values which is thick with the values of mutual cooperation and kinship, is now starting to fade and be forgotten. A logical consequence in an era development and development where intercultural introductions occur resulting in changes to the original values of a community entity. These changes tend to have a negative impact that can diminish the original values that have long grown and developed in the community, so as to eliminate the identity or characteristics of a community entity, including a sense of caring for one another.

3) The availability of various options outside the family, in the sense that the needs that are usually met by the family, can now be obtained outside, causing less dependence between husband and wife;

Interviewed with Staff Registrar, and Annual Report of the Class IA Tanjung Karang Religious Court in Bandar Lampung City, changes in people's behavior due to changing times also affect the mindset of society in viewing a marriage. Based on the data obtained, it can be seen that the divorce rate in Bandar Lampung has increased every year. Most divorce cases in the Class IA Tanjung Karang Religious Court in Bandar Lampung are filed by the woman (wife). Most of the divorces filed with the Bandar Lampung City Religious Court are motivated by constant disputes. Moral crisis is also one of the main reasons for someone to file a divorce suit in court. And the reason there is no more harmony in the family, the majority of divorce cases at the Bandar Lampung City Religious Court are experienced by middle and highly educated economic groups.

Divorce is not only seen from a legal perspective but also from a social perspective. The family as the core organization in society is crucial in shaping the future generation of the nation. Through a family, it can form a child's soul and mindset. Happy families will be able to educate their children well. This is because the division of roles between father and mother goes accordingly. This is very interesting for the author to conduct a further study in addressing social changes in the Muslim community of Bandar Lampung City related to divorce issues. Because in families that already have children, children will be victims who are very vulnerable to their impact after the judge has decided to divorce their parents. It is feared that other disputes with regard to child custody will arise, although basically it can be decided again through the court, but the argued considerations to achieve justice in exercising custody of children must be taken into account as well as possible. In other countries, for example, Chinese judges[6] prefer certain factors that are easy to ascertain, such as the financial capacity of the parents and the sustainability of the situation, over other internal emotional factors, such as the needs and emotional attachments of children.

4) The emergence of demands for equal rights for men and women, such as at this time job opportunities or positions are no longer based on gender, but on the skills a person has, so that career opportunities for women are more open.[7]

There is an ethos of equality and demands for equal rights between men and women; The equality of positions between men and women has encouraged women to be more courageous in taking positions, including to divorce rather than live under pressure from men. In addition, with the emergence of demands for equal rights for men and women[8], currently job opportunities or positions are no longer based on gender, but on one's expertise, so that career 
opportunities for women are more open. This can lead to a shift in the orientation of family building from having offspring to advancing careers.

\section{Conclusions}

Many factors cause divorce, including economic factors, infidelity by one partner, disharmony in the family, incompatibility in the household, the presence of a third party, due to early marriage, and so on.

The absence of household harmony is the main cause of divorce, followed by a moral crisis which occupies the second cause of divorce in the people of Bandar Lampung, which is 11 cases or $22 \%$, followed by absence of responsibility is the dominant factor affecting the divorce that occurs in the Muslim community of the city of Bandar Lampung. Respondents admitted that their husbands were often drunk, gamblers, and prostitutes so that the respondents were not happy with them. One example is he goes to work, it turns out that he comes home drunk and even comes home late at night, his body is unbalanced and he drinks too much.

1) Changes in the meaning contained in divorce, in the current sense that divorce is no longer considered a disgrace, in big cities the status of a widow or widower is a common thing because city people emphasize their role more than their individual status;

2) Changes in loosening supervision of relatives, friends, and neighborhoods on family integrity;

3) The availability of various options outside the family, in the sense that the needs that are usually fulfilled by the family, can now be obtained outside, causing the dependence between husband and wife to decrease;

4) The emergence of demands for equal rights for men and women, such as at this time job opportunities or positions are no longer based on gender, but on one's expertise, so that career opportunities for women are more open.

Affirming to all elements of society (the surrounding community, community leaders, the role of the government in this case through related agencies, other state officials and nongovernmental organizations to participate in educating people who will build a household ark as well as socializing and advocating for families that are threatened with breaking up marital ties through the divorce line. In addition, in every trial the judge always tries to reconcile the two parties. However, in reality the divorce rate in society is increasing. This shows that the existing laws and regulations are not effective enough to overcome the flow of divorce that occurs in society, especially in the Muslim community of Bandar Lampung. Therefore, it is necessary to increase public awareness to strengthen knowledge of the law of marriage which is not merely carrying out marriage, only ceremonially continuing the offspring or even following the trend of colleagues who were previously married.

\section{References}

[1] U. M. Ishaq, “Konsep Kebahagiaan Menurut Ibn Al-Haytham,” Islam. J. Stud. Keislam., vol. 14, no. 2, 2020, [Daring]. Tersedia pada: http://islamica.uinsby.ac.id/index.php/islamica/article/view/603/596.

[2] A. Manan et.all, Peradilan Agama Ditinjau Dari Berbagai Aspek. Bandung: E-Book Cendramata Diklat Cakim Angkatan II PPC Terpadu Seluruh Indonesia, 2013.

[3] A. A. Al Hadi, "Kedudukan Hukum Al-Sunnah dalam Al-Qur'an," Al-Daulah J. Huk. dan 
Perundangan Islam, vol. 8, no. 1., 2018, [Daring]. Tersedia pada: http://jurnalfsh.uinsby.ac.id/index.php/aldaulah/article/view/660/526.

[4] A. M. Hasyim, "The Principles Of Tightening Divorce In Semarang High Religious Court In Maqasid Al-Shari'ah Perspective.," J. Islam. Law, vol. XV, no. 1, 2015, [Daring]. Tersedia pada: https://www.neliti.com/id/publications/42627/the-principles-of-tightening-divorce-in-semarang-highreligious-court-in-maqasid.

[5] N. M. Syaefullah, "Analysis of Causing Factors Divorce in Indramayu District (Case Study in The Religion Court of Indramayu District in 2018)," Mahakim J. Islam. Fam. Law, vol. II, no. 1, 2018, [Daring]. Tersedia pada: https://jurnal.iainkediri.ac.id/index.php/mahakim/article/viewFile/974/573.

[6] X. Jianghao, "The Best Interest of the Child Principle in Residence Disputes after Parental Divorce in China," Int. J. Law. Policy. Family, vol. ebaa001, no. ebaa001, 2020, [Daring]. Tersedia pada: https://academic.oup.com/lawfam/advance-articleabstract/doi/10.1093/lawfam/ebaa001/5880239?redirectedFrom=fulltext.

[7] R. Nunung, Aspek Hukum Perceraian Dalam Kompilasi Hukum Islam. Bandar Lampung: Aura, 2018.

[8] R. Nunung, Hukum dan Hukum Islam. Semarang: Pustaka Magister, 2017.

\section{Interviewed}

Staff Registrar of the Class IA Tanjung Karang Religious Court in Bandar Lampung City 